\title{
Quantification of color variation of restorative materials used on pediatric dentistry after pigmentation
}

\author{
Quantificação da variação da cor de materiais restauradores utilizada em Odontopediatria após pig- \\ mentação
}

Luísa Bandeira Pires Monteiro LOPES

Andreia Sofia Lopes de ARAÚJO'

Virginia Barreiros MILAGRE ${ }^{1}$

\section{ABSTRACT}

\section{Objective}

To quantify the color variation of two glass ionomer cements and a composite resin used in pediatric dentistry, after being immersed in different pigments agents.

\begin{abstract}
Methods
Using two glass ionomer cements (Ketac ${ }^{\mathrm{TM}}$ Molar and Photac ${ }^{\mathrm{TM}}$ Fil) and a microhybrid composite resin (Filtek ${ }^{\mathrm{TM}}$ z250), were produced 40 disks of each material $\left(10 \mathrm{~mm}\right.$ in diameter and $2 \mathrm{~mm}$ thick). The samples were soaked in artificial saliva (control group), coke, peach lce Tea ${ }^{\circledR}$ and chocolate milk, for 72 hours in an oven at $37^{\circ} \mathrm{C}$. After this period, the samples were washed in $50 \mathrm{ml}$ of distilled water. Finally, using the spectrophotometer, it was made the reading of results. The color change was measured according to the CIE $L$ * $a$ * $b$ * system. Color changes were statistically analyzed using parametric one-way ANOVA and ANOVA with Welch correction, the nonparametric Kruskal-Wallis tests and post-hoc Tukey and Dunnet T3 with $p \leq 0.05$.
\end{abstract}

\section{Results}

The immersion of restorative materials in different pigmentation agents caused a significant color variation on the samples. The agent who presented higher results was the Peach Ice Tea ${ }^{\circledR}$. The chocolate milk was the fluid with lowest pigmentation capacity of all restorative materials under study. The

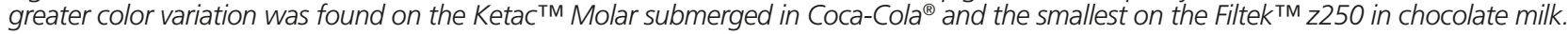

\section{Conclusion}

All restorative materials were shown to be susceptible to pigmentation by all agents. The Filtek ${ }^{\mathrm{TM}} z 250$ proved to have better color stability, followed by Photac ${ }^{\mathrm{TM}}$ Fil and finally by Ketac ${ }^{\mathrm{TM}}$ Molar.

Indexing terms: Composite resins. Glass ionomer cements. Pigmentation.

\section{RESUMO}

\section{Objetivo}

Quantificar a variação da cor de materiais restauradores utilizados emodontopediatria, após serem imersos em agentes pigmentantes.

\section{Métodos}

Recorrendo aos cimentos de ionómero de vidro Photac ${ }^{\mathrm{TM}}$ Fil e Ketac ${ }^{\mathrm{TM}}$ Molar, e à resina composta microhíbridaFiltek ${ }^{\mathrm{TM}} \mathrm{z}^{250}$, foram efectuados 40 discos de cada material (10 milímetros de diâmetro e 2 milímetros de espessura). As amostras foram imersas em saliva artificial (grupo controlo), Coca-Cola ${ }^{\circledR}$, Ice Tea ${ }^{\circledR}$ de pêssego e Leite com chocolate, durante 72 horas, numa estufa a $37^{\circ} \mathrm{C}$. Decorrido este período, as amostras foram lavadas em 50 mililitros de água destilada. Por último, através da utilização do Espectrofotómetro, procedeu-se à leitura dos resultados. A variação da cor foi medida de acordo com o sistema CIE $L^{*} a^{*} b^{*}$ e analisada estatisticamente utilizando os testes paramétricos ANOVA one-way e ANOVA com correcção de Welch, o teste não paramétrico Kruskal-Wallis e os testes post-hoc Dunnet T3 e Tukey com p $\leq$,05.

\section{Resultados}

A imersão das amostras nos fluidos, provocou uma variação de cor significativa das mesmas. O agente que apresentou resultados de pigmentação mais elevados foi o Ice Tea $₫$ de pêssego. O leite com chocolate foi o fluido que apresentou menor capacidade pigmentante em todos os materiais em estudo. A maior variação de cor verificou-se no Ketac ${ }^{T M}$ Molar em Coca-Cola ${ }^{\circledR}$ e a menor no Filtek ${ }^{T M}$ z250 em leite com chocolate.

\section{Conclusão}

Todos os materiais restauradores demonstraram ser suscetíveis à pigmentação, por parte dos agentes. O Filtek ${ }^{\mathrm{TM}}$ z250 demonstrou ter uma melhor estabilidade de cor, seguido pelo Photac ${ }^{\mathrm{TM}}$ Fil e pelo Ketac ${ }^{\mathrm{TM}}$ Molar.

Termos de indexação: Pigmentação. Cimentos de ionómero de vidro. Resinas compostas.

\footnotetext{
${ }^{1}$ Instituto Superior Ciençias Saúde Egas Moniz, Departamento de Odontopediatria. Campus Universitário, Quinta da Granja, Monte de Caparica, 2829 - 511 , Caparica, Portugal. CorrespondÇencia para / Correspondence to: LBPML THERIAGA. E-mail: <luisabpmlopes@gmail.com>.
} 


\section{INTRODUCTION}

The teeth are usually identified as an important feature in the beauty of the face, performing a major role in the relationship and iteractions between the individuals and the society". In modern times we have to consider the color change that teeth are exposed to, since the aesthetic demands by the patients have grown at an exponential level. Due to this growing interest in regard to dental esthetics, it is considered important to carry out investigations with the purpose of studying the characteristics of various restorative materials to subsequently proceed to the improvement of their physical properties, including color stability.

The theet color is determined by a combination between the intrinsic color of the tooth and the extrinsic pigments that can be formed on its surface ${ }^{2}$. Teeth discoloration can be classified as intrinsic, extrinsic or a combination of both ${ }^{3}$. The intrinsic pigmentation results from structural changes related to the thickness or composition of the dental hard tissues; the causes can be related to metabolic diseases and systemic factors that alter the tooth development and consequently its pigmentation ${ }^{2-3}$. In the extrinsic pigmentation, the responsible materials are located in the surface of the tooth or in the acquired pellicle. This pigmentation can be removed through dental prophylaxis. Among the materials responsible for the pigmentation we can find: food ingridients containing tannis, coffee, tea, red wine, tobacco, iron salts, chlorhexidine and others ${ }^{2-3}$.

Over the past 50 years there have been several changes in the development and availability of restorative materials used in odontopediatrics dentistry, with the appearance of the Composite Resins and the Glass lonomer Cement. Thus, currently the dentist has at his disposal several materials, from which he can choose the most appropriate for each type of restoration ${ }^{4}$.

The first Glass lonomer Cement (GIC) was developed by Wilson and Kent in the mid- 70's. These socalled conventional lonomers, present in its composition an aqueous solution of polyacrylic acida at a $45 \%$ concentration and a powder consisting of Fluoramino Silicate Glass, Silicon, Aluminum, Phosphorus, Fluorine, Sodium and Calcium ${ }^{5}$. The conventional GIC are widely used in children and can be used as sealants for pits and fissures, cavity liner, cementing agents and as filling material ${ }^{5}$. They are also profusely used in Atraumatic Restorative Treatment, since they have the ability to remineralize the dental hard tissues ${ }^{6}$.

In response to the disadvantages related to convencional GIC, the lonomer glass Modified Resins (RMGIC $)^{5}$ were introduced in the late 80 's offering improvements with regard to the physical properties and maintaining advantages such as adhesion and fluoride release ${ }^{7}$. As in the conventional GIC, the modified resins exhibit polyacrylic acid and a basic powdered glass in their constitution. However resinous hydrophilic monomers such as group 2-hydroxyethylmethacrylate (HEMA) and photoinitiator ${ }^{5}$ are added in its constitution. This material possess a wide variety of uses and can be applied as a restorative material, cementing material, indirect pulp protector and also as a pit and fissure sealant ${ }^{8}$, making it easy to understand why the RMGIC have gained great popularity and currently being widely used in the practice of odontopediatrics dentistry9.

The Composite Resins were first introduced in the mid-1960's ${ }^{10}$. This material possesses several applications such as: direct restorations, cavity lining, sealing of pits and fissures, core buildings, inlays, onlays, crowns, provisional restorations, cementing unit or multiple prostheses and orthodontic appliances, among others ${ }^{11}$. In its constitution we can find a polymeric matrix (organic matter), charged particles (inorganic matter), a silane, canforoquinonas that promote or modulate the polymerization reaction, and pigments $^{12}$. Despite the fact that the composite resins have been suffering several changes over the time, the pigmentation of material still constitutes a problema ${ }^{11}$.

\section{METHODS}

The Restorative materials used in this study were a Conventional Glass lonomer Cement (Ketac Molar, 3M ESPE, Minnesota, USA), a Glass lonomer Cement Modified by Resin (Photac Fil, 3M ESPE, Minnesota, USA) and a Microhybrid Composite Resin (Filtek z250, 3M ESPE, Minnesota, USA). One hundred and twenty samples in disc form were prepared, using a metallic matrix with $10 \mathrm{~mm}$ diameter and $2 \mathrm{~mm}$ of thickness. A sheet of acetate was placed between the glass plate and the metallic matrix. Forty discs were then produced with each restorative material according to the manufacturer's instructions, photopolymerizating the Glass lonomer Cement for 20 seconds and the Composite Resin for 40 seconds. The forty discs of each restorative material were then divided into four groups, ten discs from each placed into a different immersion liquid: artificial saliva (control group), Coca-Cola ${ }^{\circledR}$, chocolate milk and peach Ice-Tea ${ }^{\circledR}$. After immersed in different liquid pigments, in specific containers, the one hundred and twenty samples were stored in an oven at $37^{\circ} \mathrm{C}$, to reproduce the oral environment for 72 hours. At the end of 72 hours, the samples were washed in $50 \mathrm{ml}$ of 
distilled water, to remove possible residues existing on the surface. The reading of the samples was performed using the spectrophotometer Spectro - Shade Micro (MHT - Niederhasli, Switzerland) and the variation of the color was mesured using the CIE $L^{*} a^{*} b$. The chromatic variation was determined by the difference between the coordinates $L^{*}, a^{*}$ and $b^{*}$ obtained after the immersion of the disks in different pigmentation agents and the coordinates $L^{*}, a^{*}$ and $b^{*}$ calculated to an average of 10 discs immersed in artificial saliva (the control group). Thus, the formula used to determine the color stability was: $\Delta E=\left[\left(\text { final } L^{*}-L^{*} \text { mean of the control group }\right)^{2}+\right.$ (final $a^{*}-a^{*}$ mean of the control group $)^{2}+\left(\right.$ final $b^{*}-b^{*}$ mean of the control group) $\left.)^{2}\right]^{1 / 2}$. To test the differences of chromatic variation between groups of restorative materials and within the same group, but with different pigmentation agents, it was used the one-way ANOVA test. When the assumption of normality was not satisfied, the nonparametric test of Kruskal - Wallis was used as an alternative. When the assumption of homogeneity in the variances was not satisfied, the ANOVA test with Welch correction was applied. Mutiple comparison tests were also conducted, the Tuckey test, applied when the null hypothesis in the ANOVA test was rejected and Dunnett T3 test, when the same happened in the ANOVA test with Welch correction. The degree of significance to accept or reject the null hypothesis was $p \leq 0,05$. The statistical analysis was performed using SPSS (Statistical Package for the Social Sciences) version 20.0 for Windows.

\section{RESULTS}

The mean values of color variation $(\Delta \mathrm{E})$ and the standard deviations are shown in Table 1.
Tabel 1. Mean values of $\Delta \mathrm{E}$ and standard deviations.

\begin{tabular}{cccc}
\hline$\Delta \mathrm{E}$ & Filtek $^{\mathrm{TM}} \mathbf{z 2 5 0}$ & Ketac $^{\mathrm{TM}}$ Molar & Photac $^{\mathrm{TM}}$ Fil \\
\hline Coca-Cola $^{\circledR}$ & $1,11(0,40)$ & $22,29(1,55)$ & $5,76(0,83)$ \\
$\begin{array}{c}\text { Chocolate } \\
\text { milk }\end{array}$ & $1,07(0,40)$ & $2,28(0,55)$ & $5,00(0,41)$ \\
$\begin{array}{c}\text { Peach } \\
\text { Ice Tea }\end{array}$ & $2,67(0,46)$ & $9,33(0,53)$ & $6,10(0,47)$ \\
\hline
\end{tabular}

In the matter related with the comparison of solutions in the same restorative material, by statistical analysis, it can be concluded that there is a significant difference between the pigmentante capacity of all agents containing pigment, when applied to the Ketak ${ }^{\mathrm{TM}}$ Molar. The same does not apply between Coca-Cola ${ }^{\circledR}$ and the chocolate milk when the Filtek ${ }^{\mathrm{TM}} \mathrm{z} 250$ is subjected to its action, since the pigmentation values caused by them in this material are quite close. In the case of Photac ${ }^{\mathrm{TM}}$ Fil there is only significant differences of pigmentation between the chocolate milk and the peach Ice-Tea ${ }^{\circledR}$, being Ice-Tea ${ }^{\circledR}$ the fluid who presents the higher value of pigmentation.

In general, it is possible to claim that the peach Ice$\mathrm{Tea}^{\circledR}$ was the fluid who showed the highest pigmentante capacity in the restorative materials, the exception being the Ketac ${ }^{\mathrm{TM}}$ Molar. In this case, the pigmentante agent that caused greater chromatic change in the restorative material was the Coca-Cola ${ }^{\circledR}$. In the opposite perspective, the chocolate milk was the pigmentante agent who showed the lowest pigmentation values.

Focusing on the comparison of restorative materials, when subjected to the same pigmentante agent, after statistical analysis, it can be concluded that the difference between the pigmentation caused by the pigmentante agents is statistically significant. This fact applies for all materials when they are submitted to the action of any fluid.

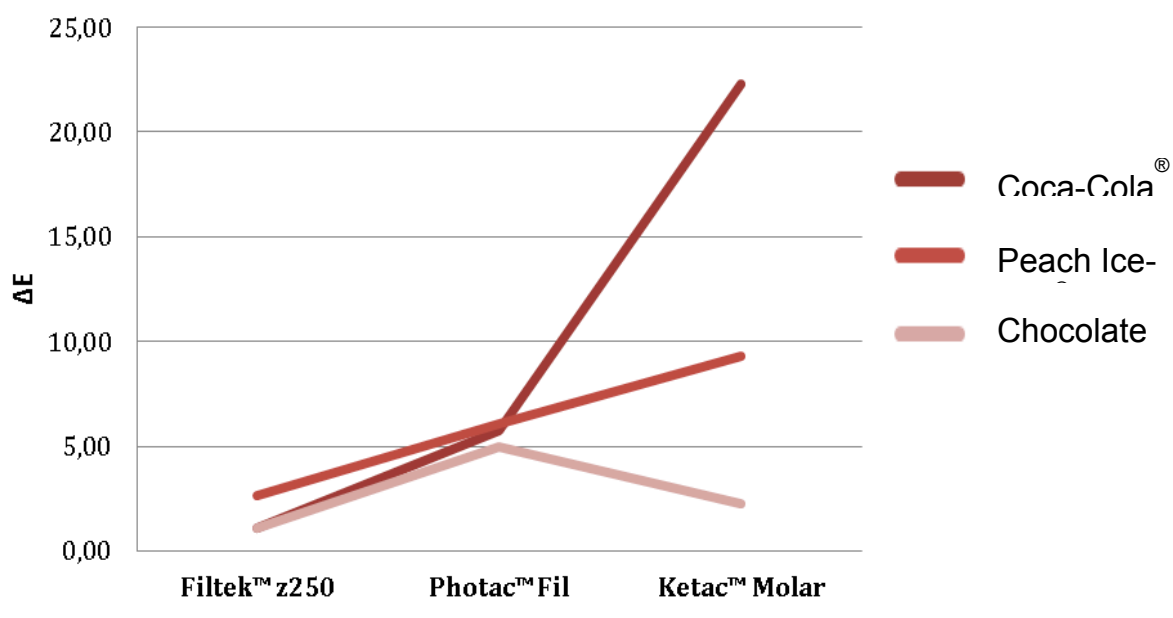

Figure 1. Compararison of restorative materials. 
In general, the material that suffered the greatest chromatic change was the Ketac ${ }^{\mathrm{TM}}$ Molar, however when the restorative materials were submitted to the chocolate milk, pigmentation values were higher for the Photac ${ }^{\mathrm{TM}}$ Fil. The Filtek ${ }^{\mathrm{TM}}$ z250, proved to be the material that suffered less color variation after being subjected to the different agents of pigmentation.

\section{Comparison of pigments agents}

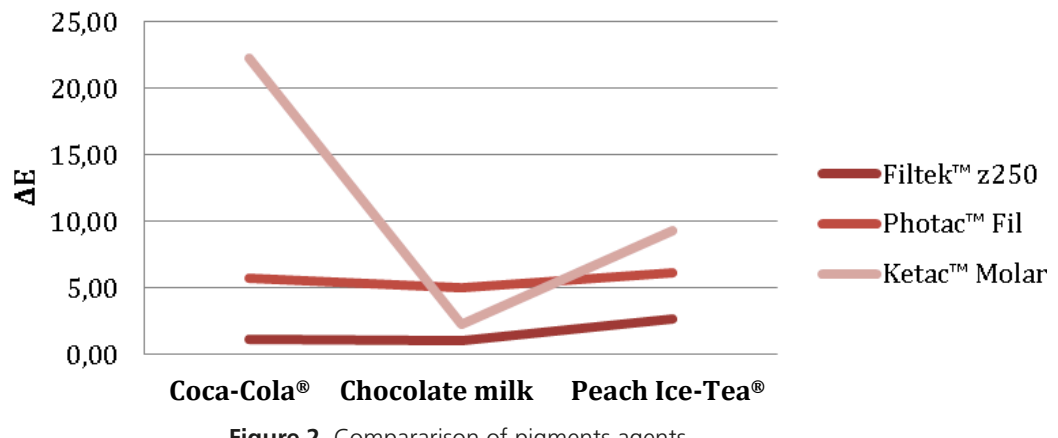

Figure 2. Compararison of pigments agents

\section{DISCUSSION}

In modern times the general population shows an increasingly concern not only with the oral health but also with their appearance. The teeth are seen as an importante feature in the beauty of the face, performing a crucial role in the interactions and the individual's relationship with society ${ }^{1}$. For the restorative material to be clinically acceptable it is important that this presents a most similar color as possible to the tooth color after the application, in order to give an aesthetic aspect, and it is also essencial that it remains over time ${ }^{13}$.

This study evaluates the color stability of three restorative materials used in the practice of pediatric dentistry, two glass ionomer cements (Ketac ${ }^{\mathrm{TM}}$ Molar and Photac ${ }^{\mathrm{TM}}$ Fil) and a microhybrid composite (Filtek ${ }^{\mathrm{TM}}$ z250), after being subjected to the action of different drinks commonly ingested by children and adolescentes. The null hypothesis suggested for this study was rejected, since there have been significant changes in the color of restorative materials before and after immersion in different agents of pigmentation.

The color determination of a tooth by visual comparison with color guides is the most often used method in clinical destistry. However during recent years there has been development of new technologies directed to analysis, communication and verification of color ${ }^{14}$.

In this investigation it was used the spectrophotometer, as it eliminates the subjectivity of the analysis done by visual comparison and considering the fact that it is one of the most useful and accurate tools in matching colors ${ }^{15}$. Since the American Dental Association recommends using the CIE L* $a^{*} b^{*}$ to evaluate possible changes in color, applying the formula of color variation $(\triangle E)$ which correlates the coordinates $L^{*} a^{*}$ and $b^{*}$, this was chosen to be used in this investigation ${ }^{16}$. The coordinate $L^{*}$ represents the lightness of the color, while the coordinates $a^{*}$ and $b^{*}$ refer to the chromatic characteristics of color. The coordinate $a^{*}$ represents the range of color from green until red, while $b$ * refers to the blue-yellow axis ${ }^{17}$.

As it was mentioned before, an essential feature for a restorative material to be clinically acceptable is the stability of its color. Several authors state that $\Delta E$ values between 1 and 3 are visible to the naked eye and above 3.3 are clinically unacceptable ${ }^{13}$.

Based on the literature, it is clear that all restorative materials in study, experienced a color change noticeable to the naked eye and apart from this fact, it is still possible to verify that considering the three materials, only the composite resin Filtek ${ }^{\mathrm{TM}}$ z250 achieved clinically acceptable results.

The color changes in dental structures and restorative materials may occur due to intrinsic and extrinsic factors. Several studies suggest that diet is one of the factors that leads to the development of extrinsic pigmentation. Restorative materials being constantly subjected to oral environment and daily exposed to salive, food and beverage, can therefore suffer changes in their color ${ }^{18-19}$.

The presence of soft drinks in the diet of the population has increased considerably in recent years, being the children and adolescentes the largest consumers of such drinks. In addition to soft drinks also chocolate milk is often present in eating habits of this age group, hence the choice of Coca-Cola ${ }^{\circledR}$, peach Ice Tea ${ }^{\circledR}$ and chocolate milk to join this study. Despite the existence of several studies testing 
the effect of Coca-Cola ${ }^{\circledR}$ in chromatic stability of various restorative materials ${ }^{13,18,20}$, the number of investigations using chocolate milk as pigmentante agent is quite limited ${ }^{18}$.

In this study the peach Ice-Tea ${ }^{\circledR}$ demonstrated a superior pigmentante capacity when compared with the other agents containing pigment, Coca-Cola ${ }^{\circledR}$ and chocolate milk. Several investigations who studied this same characteristic also show that tea has more pigmentante effect on restorative materials than Coca-Cola ${ }^{\circledR 18,20}$.

A study by Tunc et al. ${ }^{19}$ that as this research evaluated the susceptibility of Glass lonomer Cements and one Composite Resin to the pigmentation, verified that Coca-Cola ${ }^{\circledR}$ was the more pigmented solution; on the other hand, the chocolate milk was the agent that showed lower value of pigmentation, lying in accordance with what was found in this study.

The susceptibility of resinous restorative materials for pigmentation can be related to the type of polymerization, filler particles, type of pigmentant agents, among others ${ }^{20}$. This susceptibility also comes from the presence of monomers such as $\alpha$ - glycidyl methacrylate bisphenol (bis - GMA), urethane dimethacrylate (UDMA) and triethyleneglycol dimethacrylate (TEGDMA) on their matrix, making them possess a hydrophilic médium, leading to a greater absorption of water and other solutions, thereby providing a color change in the material ${ }^{18}$.

The Conventional Glass lonomer Cements (CGIC) and the ones modified by resin (RMGIC), possess different compositions, so their susceptibility to suffer pigmentation will naturally be different. Cattani-Lorente et al. ${ }^{21}$ and Small et al. ${ }^{22}$ conducted studies that show that water absorption by RMGIC is higher than that absorbed by the Conventional due to the absorption of this by the HEMA, a resinous component present in the constitution of RMGIC. Another reason that explains this difference may reside in the fact that the CGIC has greater amount of water in its composition as compared to the RMGIC, therefore it will absorb less water and consequently less pigments.

In the present investigation, the microhybrid composite resin Filtek ${ }^{\mathrm{TM}}$ z250 proved to be the restorative material less susceptible to pigmentation, and the CGIC $\mathrm{Ketac}^{\mathrm{TM}}$ Molar the material that suffers the biggest change in the color. However in the study by Tunc et al. ${ }^{19}$, the results do not match with this investigation because despite the fact that they show lower pigmentation values from Composite Resin Filtek $^{\mathrm{TM}}$ Z250 in comparison with RMGIC, the CGIC was the restorative material which showed lower values. This may be due to an increase in surface roughness of the material used in this study, thereby retaining a larger amount of pigment.
A study by Austregésilo \& Filho ${ }^{23}$, shows that the RMGIC have a smaller roughness in the surface as compared with CGIC. For a better evaluation of the materials studied, specifically with regard to the color variation after pigmentation, and in order to combat some of its limitations, it would have been interesting to introduce the analysis of surface roughness of different materials.

Another property which differentiates CGIC from RMGIC is the microhardness, since the CGIC presents higher values in that matter ${ }^{24}$. In the future, it would be interesting to conduct an investigation similar to this one, introducing the analysis of physical property, in order to check if there is any relationship between this and the susceptibility of pigmentation of restorative materials.

Several studies by different researchers, still give us account of pigmentation differences between the same materials but of different brands $13,18,20$. In a future study it would be advantageous to add several brands of the same material in order to analyze this difference.

\section{CONCLUSION}

It has occurred change in the color of all materials tested in this investigation, after their immersion in the different agents of pigmentation. The material that has suffered major change in the color after pigmentation was the Ketac ${ }^{\mathrm{TM}}$ Molar and the one who suffered minor change in the color after pigmentation was the Filtek ${ }^{\mathrm{TM}} \mathrm{z} 250$. The Ice-Tea ${ }^{\circledR}$ was the agent containing pigment that, in a general way, caused greater color variation and the chocolate milk proved to be the one who caused less change in all the tested materials. The Microhybrid Composite Filtek ${ }^{\mathrm{TM}}$ Z250 was the material that showed higher color stability, and although the color variation caused by the three agents of pigmentation is visible to naked eye, It is considered clinically acceptable. In a general way the color change observed in the Ketac ${ }^{\mathrm{TM}}$ Molar and Photac ${ }^{\mathrm{TM}}$ Fil is not only visible to the naked eye as it is not clinically acceptable.

\section{Collaborators}

JBPM LOPES was responsible for bibliography, article writing and help laboratory, both in the manufacture of discs as the collection of results. ASL ARAUJO was responsible for the confection of the discs, immersing the same in pigmentante net and reading results. Concrete elaboration of the results of the work, and participation in drafting the article. VB MIRACLE participated in the literature search and writing of the article. 


\section{REFERENCES}

1. Tin-Oo MM, Saddki N, Hassan N. Factors influencing patient satisfaction with dental appearance and treatments they desire to improve aesthetics. BioMed. 2011;11(1):6.

2. Watts a, Addy M. Tooth discolouration and staining: a review of the literature. Br Dent J. 2001;190(6):309-16.

3. Azer SS, Hague AL, Johnston WM. Effect of $\mathrm{pH}$ on tooth discoloration from food colorant in vitro. J Dent. 2010; 38(2):106-9.

4. Berg $\mathrm{JH}$. The continuum of restorative materials in pediatric dentistry - a review for the clinician. Pediatr Dent. 1998;20(2):93100.

5. Sidhu SK. Glass-ionomer cement restorative materials: a sticky subject? Aust Dent J. 2011;56(1):23-30.

6. Mickenautsch S, Mount G, Yengopal V. Therapeutic effect of glass-ionomers: an overview of evidence. Aust Dent J. 2011;56(1):10-15

7. Sidhu SK. Clinical evaluations of resin-modified glass-ionomer restorations. Dent Mater. 2010;26(1):7-12.

8. Maneenut C, Sakoolnamarka R, Tyas MJ. The repair potential of resin-modified glass-ionomer cements. Dent Mater. 2010;26(7):659-65.

9. Aguiar FHB, Georgetto MH, Soares GP, Catelan A, Dos Santos PH, Ambrosano GMB, et al. Effect of different light-curing modes on degree of conversion, staining susceptibility and stain's retention using different beverages in a nanofilled composite resin. J Esthet Restor Dent. 2011;23(2):106-14.

10. Barutcigil Ç, Yıldız M. Intrinsic and extrinsic discoloration of dimethacrylate and silorane based composites. J Dent. 2012;40(1):57-63.

11. Ferracane JL. Resin composite--state of the art. Dent Mater. 2011;27(1):29-38.

12. Hervás-García A, Martínez-Lozano MA, Cabanes-Vila J, BarjauEscribano A, Fos-Galve P. Composite resins. A review of the materials and clinical indications. Med Oral Patol Oral Cir Bucal. 2006;11(2):215-20.

13. Mundim FM, Garcia LDFR, Pires-de-Souza FDCP. Effect of staining solutions and repolishing on color stability of direct composites. J Appl Oral Sci. 2010;18(3):249-54.
14. Chu SJ, Trushkowsky RD, Paravina RD. Dental color matching instruments and systems. Review of clinical and research aspects. J Dent. 2010;38(2):2-16.

15. Paul S, Peter A, Rodoni L, Pietrobon N. Conventional visual vs spectrophotometric shade taking for porcelain-fused-to-metal crowns: a clinical comparison. Int J Periodontics Restorative Dent. 2004;24(3):222-31.

16. Ayad NM. Susceptibility of restorative materials to staining by common beverages: an in vitro study. Eur J Esthet Dent. 2007; 2(2):236-47.

17. Moreira AD, Mattos $C T$, De Araújo MVA, Ruellas ACDO, Sant'Anna EF. Chromatic analysis of teeth exposed to different mouthrinses. J Dent. 2013;41(5):24-7.

18. Bagheri R, Burrow MF, Tyas M. Influence of food-simulating solutions and surface finish on susceptibility to staining of aesthetic restorative materials. J Dent. 2005:33(5):389-98.

19. Tunc E Sen, Bayrak S, Guler AU, Tuloglu N. The effects of children's drinks on the color stability of various restorative materials. J Clin Pediatr Dent. 2009;34(2):147-50.

20. Guler AU, Yilmaz F, Kulunk T, Guler E, Kurt S. Effects of different drinks on stainability of resin composite provisional restorative materials. J Prosthet Dent. 2005;94(2):118-24.

21. Cattani-Lorente MA, Dupuis V, Payan J, Moya F, Meyer JM. Effect of water on the physical properties of resin-modified glass ionomer cements. Dent Mater. 1999;15(1):71-8.

22. Small ICB, Watson TF, Chadwick AV, Sidhu SK. Water sorption in resin-modified glass-ionomer cements: an in vitro comparison with other materials. Biomaterials. 1998;19(6):545-50.

23. Austregésilo SC, Filho PFM. Avaliação da rugosidade superficial de cimentos ionoméricos convencionais e modificados. XVII Congresso de Iniciação Científica. 2009. p. 27-30.

24. Xie D, Brantley WA, Culbertson BM, Wang G. Mechanical properties and microstructures of glass-ionomer cements. Dent Mater. 2000;16(2):129-38.

Received on: 4/12/2014 Final version resubmitted on: 27/3/2015 Approved on: 10/9/2015 